\title{
The Proof is in the Appendage: A Case Report of a Fenestrated Membrane Overlying the Left Atrial Appendage
}

\author{
Jaime Holbert ${ }^{1}$, Ben Shepple ${ }^{1}$, Bret Rogers ${ }^{1}$, and Jeffrey Hirsh ${ }^{1}$ \\ ${ }^{1}$ The University of Tennessee Medical Center
}

May 6, 2020

\begin{abstract}
A 35-year-old male with history of recurrent arrhythmias presented for pulmonary vein isolation. He underwent pre-procedural screening for thromboembolism risk with transesophageal echocardiogram. He had an incidental finding of a rare fenestrated membrane overlying his left atrial appendage. Additional work-up throughout his clinical course revealed genetic mutations in the LMNA and SNTA1 genes. There have been no previous reported genetic mutations reported in cases with LAA membranes.
\end{abstract}

The Proof is in the Appendage:

A Case Report of a Fenestrated Membrane Overlying the Left Atrial Appendage

Short Title: Fenestrated LAA Membrane

Jaime Holbert, DO, MS (Corresponding Author)

JHolbert1@utmck.edu

Ben Shepple, MD

BShepple@utmck.edu

Bret Rogers, MD

BARogers@utmck.edu

Jeffrey Hirsh, MD

JHirsh@utmck.edu

University of Tennessee Medical Center

Department of Medicine

1924 Alcoa Highway Ste U-114

Knoxville, TN 37920

Ph: (865) 305-9340 F: (865) 305-9144

\section{Declarations/disclosures}

Dr. Jeffrey Hirsh - Speaker's Bureau, Zoll

The remaining authors have no relevant declarations of interest or disclosures. The authors have no conflicts of interest. This research did not receive any specific grant from funding agencies in the public, commercial, or not-for-profit sectors. 


\section{Hosted file}

LAA Membrane Echo.docx available at https://authorea.com/users/318357/articles/448288-theproof-is-in-the-appendage-a-case-report-of-a-fenestrated-membrane-overlying-the-leftatrial-appendage
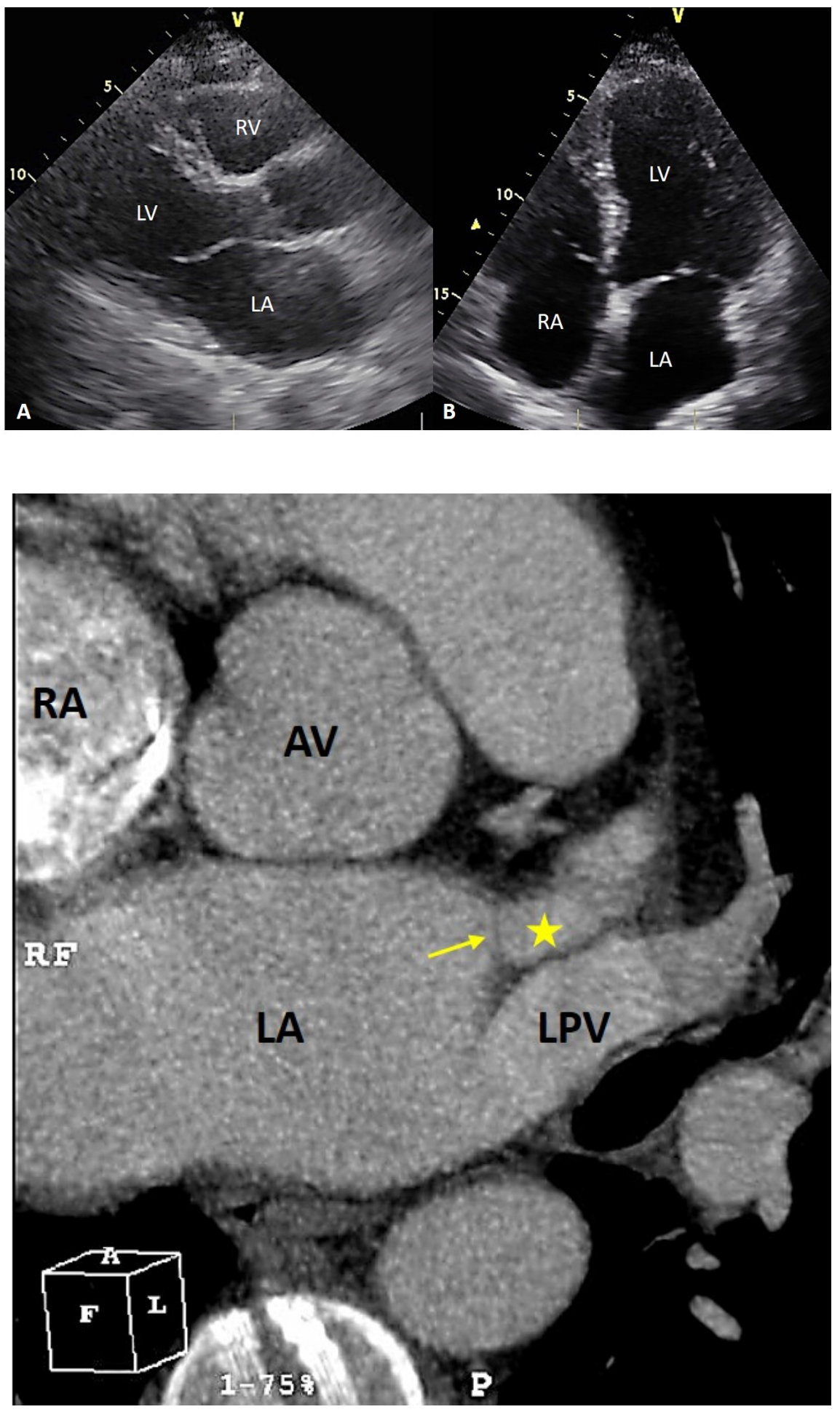

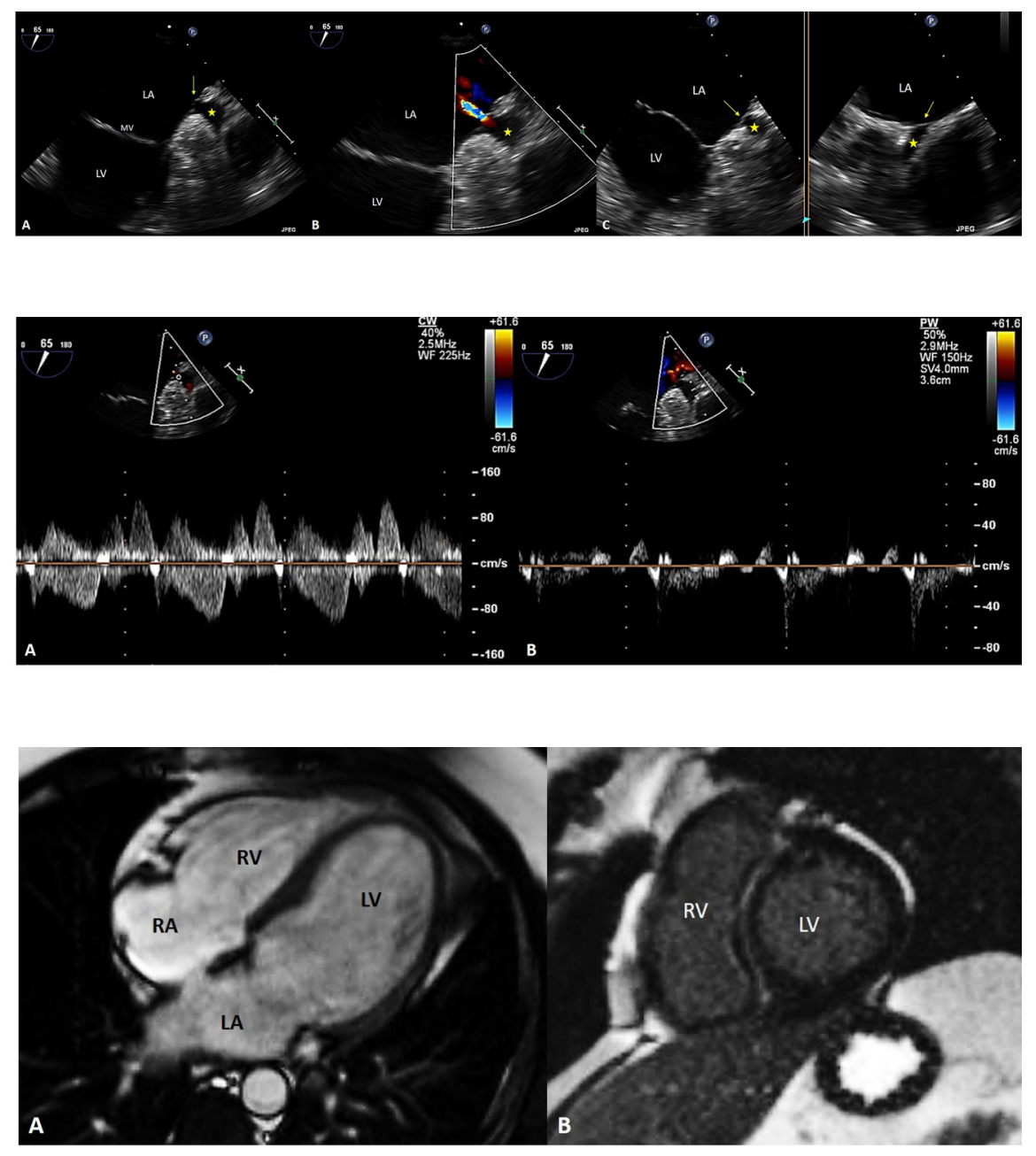